\title{
PEMETAAN ZONA RESIKO PENULARAN COVID-19 DI SULAWESI SELATAN MENGGUNAKAN PLOT DENDROGRAM HIERARCHICAL CLUSTERING
}

\author{
(Mapping Of The Risk Zone Of Transmission Of Covid-19 In South Sulawesi Using A \\ Hierarchical Clustering Dendrogram Plot)
}

\author{
Muhammad Ilham Mubarok ${ }^{1}$, Aris Rusyiana² \\ Bidang Neraca Wilayah dan Analisis Statistik, Badan Pusat Statistik Provinsi Sulawesi Selatan ${ }^{1}$ \\ Biro Bina Program, Badan Pusat Statistik²
}

Jalan H. Bau No. 6, Makassar, Sulawesi Selatan 90125

E-mail: ilham.mubarok@bps.go.id

\begin{abstract}
ABSTRAK
Provinsi Sulawesi Selatan merupakan salah satu provinsi di urutan teratas yang angka positif Covid-19 tinggi. Juga, penambahan kasus harian dan jumlah kematian pasien akibat Covid-19 relatif tinggi. Mencermati keadaan ini, diperlukan kajian yang dapat memetakan resiko penanggulangan Covid-19 dari segi statistik pandemi (total kasus kumulatif, pasien sembuh, pasien meninggal, dan pasien dirawat) dikombinasi dengan karakteristik ekonomi, kesehatan, sosial, dan demografi kabupaten/kota. Penelitian ini menggunakan desain penelitian kuantitatif menggunakan data statistik resmi BPS dan pemerintahan terkait, untuk menyusun peta clustering zonasi daerah pandemi covid 19 kabupaten/kota, serta analisis kluster berjenjang dendrogram (dendrogram hierarchical clustering) dalam ruang lingkup regional Provinsi Sulawesi Selatan. Menggunakan peta tematis total kasus dan dendrogram kluster berjenjang, kami membagi ke dalam 4 (empat) kluster, yaitu kluster 1 (rendah), klaster 2 (sedang), klaster 3 (waspada), klaster 4 (berbahaya). Kami menemukan bahwa ibu kota provinsi, Makassar, ada di klaster 4 dengan karakteristik: kasus positif pasien Covid-19 terbanyak dan tingkat kepadatan penduduk terpadat. Di sisi lain, Makassar ini menunjukkan ketahanan dari segi sudut pandang faktor penawaran (supply factor) dukungan fasilitas kesehatan, baik yang berhubungan dengan rumah sakit, fasilitas kesehatan primer (puskesmas), maupun fasilitas kesehatan berbasis komunitas (posyandu), dan juga tenaga kesehatan terbesar. Sedangkan Gowa, dan Bone termasuk di cluster/zona 3 sebagai kabupaten yang dekat dengan episenter, yang memiliki karakteristik kasus pasien positif Covid-19 kedua terbanyak dari kab/kota di zona 1, dan didukung angka kepadatan penduduk yang lebih renggang dibandingkan zona 4, dan didukung oleh faskes dan nakes terbesar kedua dibandingkan kabupaten/kota di zona 1. Temuan sementara dari kajian ini dapat dipertimbangkan untuk menjadi acuan makalah kajian mendatang untuk menghitung indeks komposit resilient (sudut pandang optimis) atau indeks komposit kerentanan (sudut pandang pesimis) terhadap pandemi Covid-19, yang akan berguna untuk regional, nasional, bahkan dunia. Kontribusi sementara dari study ini yang dapat diberikan kepada pemerintah di Provinsi Sulawesi Selatan adalah peningkatan kualitas koordinasi tanggap darurat Covid-19, contohnya di dalam pembatasan mobilitas penduduk. Bila mau melakukan kebijakan perpanjangan Pembatasan Sosial Berskala Besar (PSBB), pemerintah daerah zona 4 dan 3 harus kompak, terutama membatasi mobilitas penduduk dari dan ke klaster 2 dan 1 dengan resiko rendah. Hal berikutnya, dengan mempertimbangkan realokasi bantuan langsung dari daerah di klaster 1 dan 2 untuk daerah di klaster 3 dan 4 , tentu saja dengan tetap memperhitungkan kewenangan dan aturan yang ada.
\end{abstract}

Kata kunci: Analisis Klaster Hierarki Dendrogram, Peta Zonasi, Covid-19 Sulawesi Selatan

\section{ABSTRACT}

Recently, South Sulawesi Province is one of the five provinces with a high positive rate of Covid-19 in Indonesia. Also, this province shows the positive rate and death rate due to Covid-19 increases daily. Observing this situation, we conduct a study to cluster the risk of handling Covid-19 in terms of pandemic statistics (total cumulative cases, patients recovered, patients died, and patients treated) in entirelt districts and municipality of South Sulawesi Provinces. We also examine the hierarchical clustering of info-demics with the economic, health, social and demographic characteristics of districts/cities nexus. This study uses a quantitative research design using official statistical data from BPS and related governments, to cluster 19 districts/cities of the Covid-19 pandemic areas into 4 areas, as well as to analyze a dendrogram hierarchical 
clustering within the regional scope of South Sulawesi Province. We categorize districts/municipality of South Sulawesi Provinces into 4 (four) clusters, namely 1st cluster (low), 2nd cluster (moderate), 3rd cluster (alert), 4th cluster (dangerous). We find that Makassar City relates to cluster 4 with the following characteristics: highly positive cases of Covid-19 patients and densedly populated areas. On the other hand, Makassar, a capital city of South Sulawesi Province, shows resilience from the point of view of the supply factor for health facilities support, whether related to hospital health care facilities, primary health facilities (puskesmas), or community-based health facilities (posyandu), as well as largest health personnel. Meanwhile, Gowa and Bone are included in the 3rd cluster as two closest districts to the epicenter of Covid19 outbreakes in Makassar, which have the second highest number of positive case characteristics for Covid19 patients from districts/cities in the 1st zone, and are supported by population density figures that are more tenuous than the 4th zone, and supported by health facilities and health workers, the second largest compared to districts/cities in the 1st zone. Despites our immature findings, this study could give important suggestion that Government of South Sulawesi Provinces and the entirely districts/cities may take into account and look closer for the readiness policy to combat the Covid-19. This study suggests that South Sulawesi province's decision makers should improve the quality of coordination for the Covid-19 emergency response, for examples in limiting citizens' mobility and extending Large-Scale Social Restrictions (PSBB). For upcoming studies, researchers could go futher in calculating a composite resilient index (optimistic point of view) or a composite index of vulnerability (pessimistic point of view) to the Covid-pandemic. 19, which will be useful for regional, national, and even international.

Keywords: Dendrogram Hierarchy Cluster Analysis, Zoning Map, Covid-19 South Sulawesi

\section{PENDAHULUAN}

Hampir genap 7 (tujuh) bulan, pandemi virus korona (Covid-19) telah melanda 215 Negara, 15.363.843 total kasus positif korona, 278.625 penambahan kasus baru, 629.288 kematian (Worldometer, 2020). Pandemi Covid-19 ini juga telah berdampak di Indonesia. Angka-angka statistik mengenai kasus pasien positif Covid-19 dari Kementrian Kesehatan RI, BNPB dan Gugus Tugas Nasional Penanggulangan Covid-19 terus menghiasi media massa dan media sosial, termasuk angka statistik Provinsi Sulawesi Selatan termasuk urutan 5 (lima) teratas provinsi dengan penambahan kasus harian dan jumlah kematian pasien akibat Covid-19.

Diilhami oleh pemanfaatan analisa klaster untuk monitoring pandemi Covid-19 di negara negara lain (Kumar, 2020; Poompaavai \& Manimannan, 2019; Srivastava \& Chowell, 2020), penelitian ini mengusulkan plot clustering secara berjenjang karakteristik kabupaten/kota di Provinsi Sulawesi Selatan untuk memetakan resiko penanggulangan Covid-19 dari segi statistik pandemi (total kasus kumulatif, pasien sembuh, pasien meninggal, dan pasien dirawat); pemetaan supply factor ekonomi dan kesehatan (DAU/DAK/PAD, jumlah dokter, perawat, rumah sakit, puskesmas, dan fasilitas kesehatan berbasis komunitas), dan demand factor sosial ekonomi dan demografi (jumlah penduduk, kepadatan penduduk).

Kajian pemanfaatan analisa klaster untuk monitoring statistik pandemi dan klastering kabupaten/kota di Indonesia berdasarkan karakteristik ekonomi, sosial, demografi dan kesehatan masih langka. Dengan mempertimbangkan kelangkaan pustaka yang memanfaatkan analisa klaster untuk monitoring pandemi Covid-19 di Provinsi di Indonesia, kami tertarik untuk mengajukan suatu kajian yang menggunakan metode Dendrogram Hierarchical Clustering untuk memberikan gambaran secara deskriptif mengenai 2 (dua) hal, yaitu: (1) Peta zonasi total kasus Covid-19 kabupaten/kota di Provinsi Sulawesi Selatan, (2) Dendrogram Klaster Berjenjang kabupaten/kota, karakteristik sosial, ekonomi, demografi dan kesehatan.

Kajian ini kami maksudkan sebagai kajian pendahuluan untuk eksplorasi karakteristik kewilayahan, khususnya di Provinsi Sulawesi Selatan di dalam menghadapi pandemi Covid-19. Harapannya ada studi lanjutan, yaitu penyusunan indeks ketahanan (resilient index) yang dapat mengukur ketahanan kabupaten/kota di dalam menghadapi situasi sulit akibat pandemi Covid-19. Kajian di Provinsi Sulawesi Selatan ini semoga dapat memantik kajian mengenai penyusunan indeks ketahanan terhadap pandemi ini, supaya terus menumbuhkan sudut pandang optimistis, dan yakin bahwa dengan modal sosial yang Indonesia punya, khususnya modal sosial di Provinsi Sulawesi Selatan, bisa bahu membahu keluar dari situasi tidak mudah akibat pandemi Covid-19. 
Secara umum, makalah kami ini tersusun secara sistematis, sebagai berikut: (1) bagian pendahuluan, menerangkan secara singkat situasi darurat pandemi Covid-19 Sulawesi Selatan, tujuan penelitian, dan kesenjangan penelitian; (2) Metode, yang menerangkan secara global bagaimana analisis klaster berjenjang dan Dendrogram, serta peta zonasi dapat menerangkan secara deskriptif statistik pandemi dan klastering kabupaten/kota di Provinsi Sulawesi Selatan berdasarkan karakteristik ekonomi, sosial, demografi dan kesehatan masih langka; (3) Hasil dan Pembahasan; (4) Kesimpulan; (5) Daftar Pustaka.

\section{METODE}

Penelitian ini menggunakan desain penelitian kuantitatif menggunakan data statistik resmi BPS dan pemerintahan terkait, untuk menyusun peta clustering zonasi daerah pandemi Covid-19 kabupaten/kota, serta analisis hirarki dendrogram (dendrogram hierarchical clustering) dalam ruang lingkup regional Provinsi Sulawesi Selatan. Analisis hirarki penelitian ini menggunakan jarak euclidean dengan agglomerative hierarchical methods (bottom-up strategy).

Analisis klaster adalah metode statistika multivariat yang bertujuan untuk mengelompokkan objek-objek yang memiliki kemiripan karakteristik ke dalam suatu klaster (Larasati, 2017). Objek dapat berupa benda (barang atau jasa) atau orang (responden, konsumen, dll). Objek tersebut akan diklasifikasikan ke dalam satu atau lebih klaster sehingga objek yang ada dalam satu klaster akan memiliki kemiripan satu dengan yang lain. Klaster yang baik akan memiliki homogenitas yang tinggi antar anggota klaster (within cluster) dan heterogenitas yang tinggi antar klaster yang satu dengan lainnnya (between cluster).

Proses analisis cluster yaitu:

1. Mengukur kesamaan antar obyek (similarity). Biasanya untuk data metrik digunakan korelasi dan distance (jarak), dan pengukuran jarak yang paling populer adalah metode euclidean distance, sedangkan untuk data nonmetrik digunakan asosiasi antar objek.

2. Membuat klaster, proses ini adalah proses pengelompokkan data yaitu bisa dilakukan dengan dua metode:

\section{a. Hierarchical Method}

Metode ini dimulai dengan pengelompokkan dari dua atau lebih obyek yang mempunyai kesamaan yang paling dekat. Kemudian proses diteruskan ke obyek lain yang mempunyai kedekatan kedua, demikian seterusnya.

b. Nonhierarchical Method

Berbeda dengan metode hierarki, metode ini dimulai dengan menentukan terlebih dulu jumlah klaster yang diinginkan. Metode ini biasa disebut K-Means Clustering.

3. Setelah klaster terbentuk apakah dengan metode hierarki atau nonhierarki langkah selanjutnya adalah interpretasi terhadap klaster yang telah terbentuk, yang pada intinya adalah memberi nama spesifik untuk menggambarkan isi klaster.

4. Melakukan validasi dan profiling klaster. Klaster yang terbentuk kemudian diuji apakah hasilnya valid atau tidak. Kemudian dilakukan proses profiling untuk menjelaskan karakterisktik tiap klaster berdasar profil tertentu.

\section{Analisis klaster hirarki (Hierarchical Method)}

Pada metode analisis klaster hirarki dibentuk dekomposisi secara hirarki dari data yang diperoleh. Suatu metode hirarki dapat diklasifikasikan menjadi dua yaitu agglomerative dan divisive tergantung bagaimana dekomposisi hirarki terbentuk.

Agglomerative hierarchical methods (bottom-up strategy) dimulai dengan satu objek. Pada awalnya terdapat banyak klaster yaitu sebanyak objek, kemudian objek yang paling mirip dikelompokkan pertama kali dan kelompok awal tersebut digabung dengan kelompok lain berdasarkan tingkat kemiripannya. Semakin rendah tingkat kemiripan, maka semua sub kelompok digabung menjadi satu klaster tunggal. Divisive hierarchical methods (top-down strategy) bekerja berlawanan arah dengan agglomerative. Pada awalnya terdapat suatu kelompok tunggal dari objek pada data. kemudian kelompok tersebut dibagi menjadi dua sub kelompok sedemikian hingga objek-objek pada satu sub kelompok jauh dari objek-objek pada kelompok lain. Sub 
kelompok - sub kelompok tersebut kemudian dibagi ke dalam sub kelompok - sub kelompok yang berbeda, proses berlanjut hingga banyak kelompok sama dengan banyak objek atau dengan kata lain tiap objek membentuk satu kelompok. Hasil dari kedua metode tersebut, agglomerative maupun divisive dapat disajikan dalam suatu bentuk diagram yang disebut dendogram.

Dendrogram adalah hierarki bertingkat di mana cluster di satu tingkat digabungkan untuk membentuk cluster di tingkat berikutnya. Hal ini memungkinkan untuk memutuskan tingkat di mana untuk memotong pohon untuk menghasilkan kelompok objek data yang sesuai (Kassambra, 2017).

Pengukuran distance (jarak) menggunakan formula euclidean. Diketahui untuk vektor $x_{i}$ dan $x_{j}$ maka $d_{i j}=d\left(x_{i}-x_{j}\right)$ sehingga $d\left(x_{i} x_{j}\right)=d_{i j}=\sqrt{\sum_{k=1}^{p}\left(x_{i k}-x_{j k}\right)^{2}}$ dengan $p$ adalah jumlah komponen vektor $\mathrm{x}$ (jumlah variabel) dan $x_{i} x_{j}$ adalah dua vektor yang jaraknya akan dihitung.

Algoritma Hierarchical Clustering untuk membentuk dendogram (Kassambra, 2017).

1. Menghitung dissimilarity untuk setiap pasangan kombinasi objek di dalam kumpulan data.

2. Menggunakan fungsi complete linkage untuk mengelompokkan objek ke dalam hierarchical cluster tree (dendogram), berdasarkan informasi jarak dari langkah 1. Objek yang berdekatan dihubungkan bersama menggunakan fungsi linkage.

3. Menentukan dimana melakukan pemotongan hierarchical cluster tree (dendogram) untuk menjadi beberapa kelompok. Hasil pemotongan tersebut merupakan klaster yang terbentuk.

\section{HASIL DAN PEMBAHASAN}

Berdasarkan hasil pengolahan yang telah dilakukan, peneliti membuat beberapa plot dan tabel sebagai representasi hasil yang diperoleh. Peneliti menggunakan software excel untuk melakukan pengolahan tabel dan software RStudio untuk melakukan analisis clustering serta visualisasi.

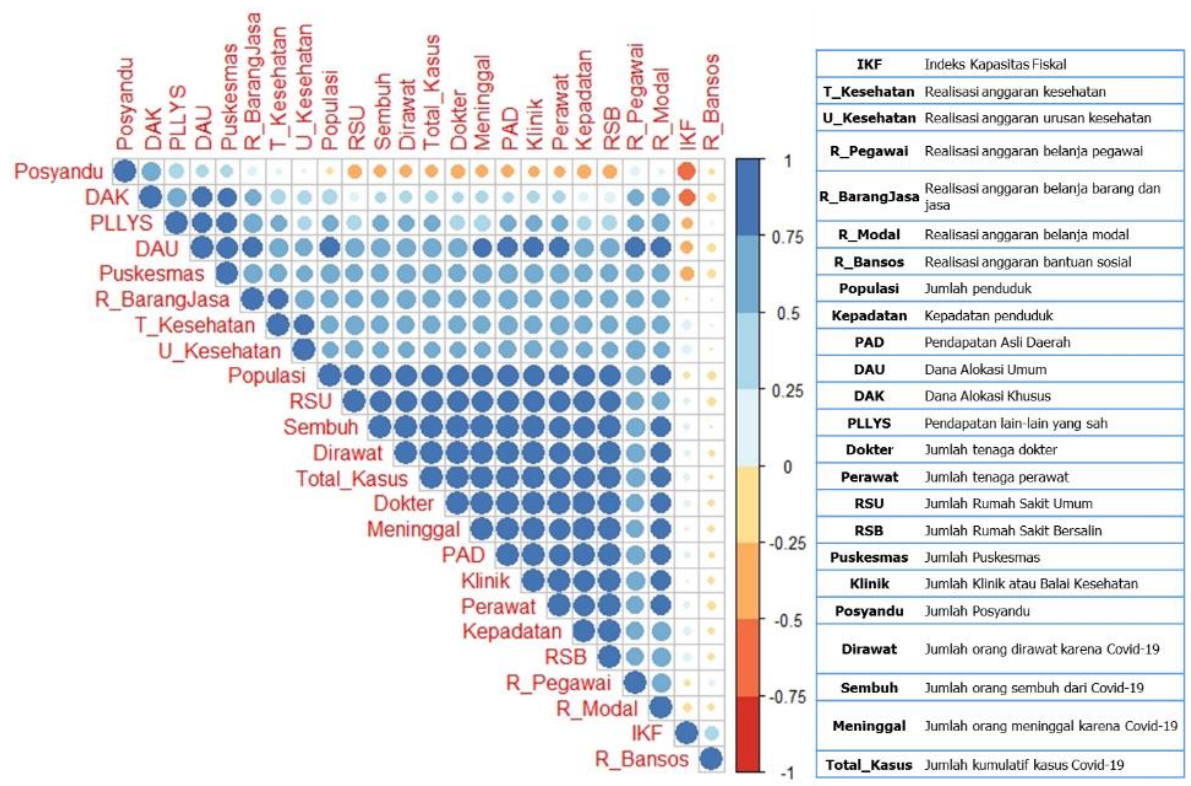

Gambar 1. Correlation plot antarvariabel.

Gambar 1 menyajikan correlation plot untuk setiap pasangan variabel dengan keterangan semakin berwarna biru gelap menunjukkan semakin berkorelasi positif (mendekati 1) dan semakin berwarna merah gelap menunjukkan semakin berkorelasi negatif (mendekati -1). Terlihat bahwa korelasi R_Bansos dengan variabel lainnya mendekati nol, terdapat korelasi negatif Indeks Kapasitas Fiskal (IKF) dengan Posyandu dan Dana Alokasi Khusus (DAK), sedangkan sebagian besar lainnya berkorelasi positif baik lemah maupun kuat (mendekati 1). Correlation plot dapat 
menunjukkan apakah hubungan antarvariabel berjalan searah atau berlawanan arah. Misalkan IKF tinggi berbanding terbalik dengan Posyandu yang rendah.

Gambar 2 menyajikan dendrogram hasil klastering secara berjenjang karakteristik kabupaten/kota dan peta kluster zonasi kabupaten/kota di Provinsi Sulawesi Selatan. Baik dendrogram maupun peta zonasi, mengelompokkan kabupaten/kota menjadi 4 (empat) klaster, yaitu klaster 1 (rendah), klaster 2 (sedang), klaster 3 (waspada), klaster 4 (berbahaya). Terdapat 17 kabupaten/kota di klaster 1, yaitu: Barru, Bantaeng, Enrekang, Toraja Utara, Luwu Utara, Maros, Sinjai, Janeponto, Sidrap, Takalar, Pinrang, Soppeng, Tana Toraja, Luwu, Wajo, Bulukumba, dan Pangkajene Kepulauan. Kemudian terdapat 4 (empat) kabupaten/kota yang termasuk di klaster 2, yaitu: Luwu Timur, Selayar, Palopo, dan Pare-Pare. Adapun klaster ketiga di zona waspada ada 2 (dua) kabupaten, yaitu Bone dan Gowa. Klaster ketiga ini dekat dengan klaster keempat, yaitu klaster berbahaya, yaitu Kota Makassar. Kota Makassar ini juga untuk saat ini bisa dianggap sebagai pusat penyebaran pandemi Covid-19 di Provinsi Sulawesi Selatan.

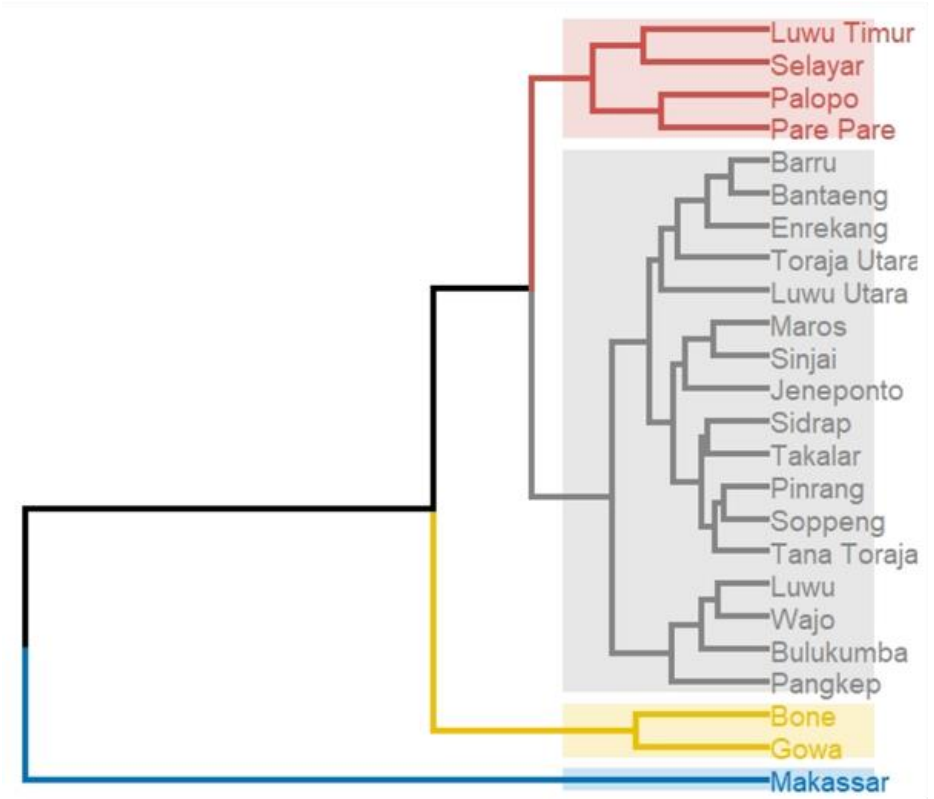

(A)

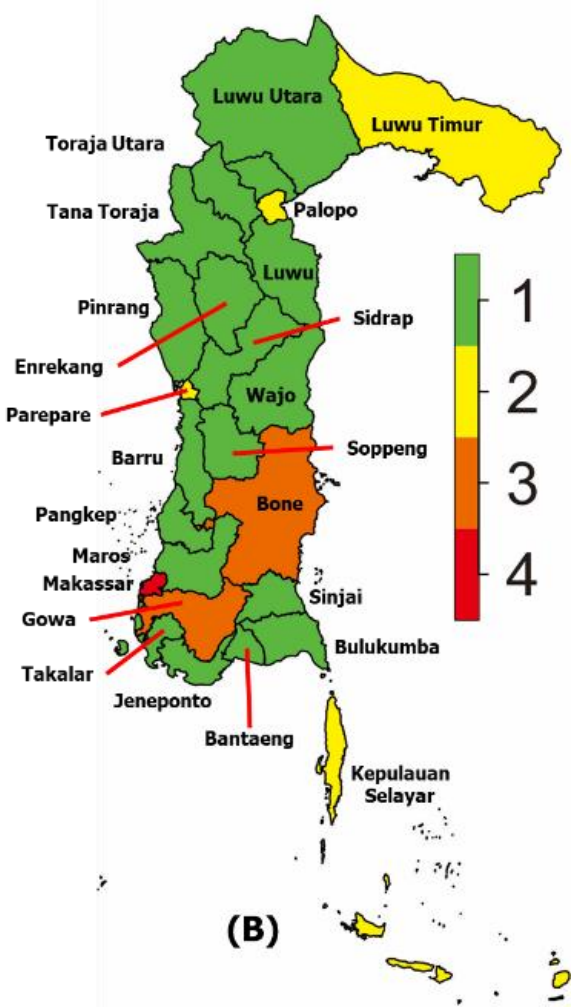

Gambar 2. (A) Dendogram hasil hierarchical clustering dan (B) Peta klaster zonasi kabupaten/kota seSulawesi Selatan.

Secara umum, baik peta tematik maupun dendrogram mampu menggambarkan 4 (empat) zona kabupaten/kota di Provinsi Sulawesi Selatan di masa pandemi Covid-19 ini. Secara umum, karakteristik statistik kabupaten/kota tiap klaster disajikan di tabel 1. Dan secara detail, statistik deskriptif dan karakteristik setiap klaster dapat dijelaskan di tabel 2 dan tabel 3.

Secara ringkas, tabel 1 menyajikan nilai rata-rata, standar deviasi, dan nilai terkecil serta terbesar dari semua karakteristik variabel kabupaten/kota di Provinsi Sulawesi Selatan, untuk aspek data Kapasitas Fiskal Daerah, Karakteristik Ekonomi, Sosial, dan Demografis, Kapasitas Tenaga Kesehatan (Nakes) serta Layanan Kesehatan (Nakes) yang berbasis fasilitas kesehatan perawatan rujukan (RSU/RSB), fasilitas kesehatan perawatan primer (puskesmas), juga fasilitas kesehatan yang berbasis komunitas (posyandu) serta angka-angka statistik pandemi Covid-19 untuk semua kabupaten/kota di Provinsi Sulawesi Selatan. Angka-angka statistik pandemi ini meliputi jumlah pasien dirawat, sembuh, meninggal, dan total kasus penderita Covid-19 di setiap kabupaten/kota di Provinsi Sulawesi Selatan.

Rata-rata total kasus positif Covid-19 di Provinsi Sulawesi Selatan sebanyak 303 kasus, dengan standar deviasi 901, dan terendah 8 kasus, serta tertinggi ada 4.430 kasus. Rata-rata pasien yang masih dirawat sebanyak 149 pasien, terendah 4 pasien dan tertinggi 2.118 kasus, 
dengan standar deviasi sebesar 430 kasus. Sedangkan rata-rata jumlah pasien yang sembuh 144 pasien, terendah 2 orang, dan tertinggi 2114 orang, dengan standar deviasi (432). Yang menyedihkan tentu saja, rata-rata pasien yang meninggal di seluruh provinsi Sulawesi Selatan 10 orang, dengan sebaran nilai terkecil dari kabupaten/kota yang nol kasus, sampai 200 kasus (standar deviasi=40,58). Data ini diambil pada 23 Juli 2020 pukul 09.24 WITA di covid19.sulselprov.go.id.

Tabel 1. Ringkasan statistik deskriptif karakteristik kabupaten/kota di Provinsi Sulawesi Selatan 2020.

\begin{tabular}{lrrrr}
\hline \multicolumn{1}{c}{ Variabel } & \multicolumn{1}{c}{ Mean } & Standar Deviasi & Minimal & \multicolumn{1}{c}{ Maksimal } \\
\hline IKF & 0.40 & 0.26 & 0.13 & 1.34 \\
T_Kesehatan & $221,222,952.58$ & $75,377,579.17$ & $119,318,173.00$ & $434,680,310.00$ \\
U_Kesehatan & $202,372,437.79$ & $81,950,103.35$ & 0.00 & $402,746,665.00$ \\
R_Pegawai & $91,134,598,475.07$ & $30,712,623,023.91$ & $38,336,584,699.00$ & $181,765,307,383.00$ \\
R_BarangJasa & $141,925,666,794.29$ & $55,801,437,649.56$ & $75,461,658,316.00$ & $300,713,260,687.00$ \\
R_Modal & $48,178,060,960.75$ & $18,221,923,852.71$ & $25,493,938,900.00$ & $111,923,004,489.00$ \\
R_Bansos & $2,538,089,583.33$ & $4,478,113,744.65$ & 0.00 & $15,600,000,000.00$ \\
Populasi & 343.83 & 284.61 & 136.60 & $1,526.70$ \\
Kepadatan & 650.63 & $1,736.69$ & 42.00 & $8,686.00$ \\
PAD & $225,241,865,245.74$ & $330,069,037,916.37$ & $73,650,896,662.00$ & $1,749,402,916,000.00$ \\
DAU & $707,660,050,125.00$ & $202,806,742,290.78$ & $486,224,602,000.00$ & $1,408,063,374,000.00$ \\
DAK & $254,572,947,758.38$ & $79,154,018,675.74$ & $121,191,749,000.00$ & $464,396,322,000.00$ \\
PLLYS & $250,956,160,150.90$ & $125,909,945,651.48$ & $81,765,348,300.00$ & $589,989,027,000.00$ \\
Dokter & 171.92 & 356.21 & 32.00 & $1,836.00$ \\
Perawat & 682.08 & 872.29 & 246.00 & $4,619.00$ \\
RSU & 3.08 & 4.30 & 1.00 & 22.00 \\
RSB & 1.13 & 4.89 & 0.00 & 24.00 \\
Puskesmas & 19.13 & 8.59 & 6.00 & 46.00 \\
Klinik & 12.13 & 28.42 & 0.00 & 143.00 \\
Posyandu & 360.50 & 208.89 & 1.00 & 985.00 \\
Dirawat & 148.75 & 430.02 & 4.00 & $2,118.00$ \\
Sembuh & 143.83 & 431.74 & 2.00 & $2,112.00$ \\
Meninggal & 10.21 & 40.58 & 0.00 & 200.00 \\
Total_Kasus & 302.79 & 900.61 & 8.00 & $4,430.00$ \\
\hline Sumber: Dirang & & &
\end{tabular}

Sumber: Dirangkum dari publikasi BPS dan data stastik resmi pemerintah.

Sumber daya tenaga medis di Provinsi Sulawesi Selatan, baik dokter maupun perawat sekitar 172 dokter dan 682 perawat. Tersebar di 24 kabupaten/kota, terdapat paling sedikit 32 (dokter) dan 246 (perawat), dan terbanyak ada 1836 (dokter) serta 4619 (perawat). Kemudian, terdapat Rumah Sakit Umum (RSU) dan Rumah Sakit Bersalin (RSB) rata-rata berjumlah sekitar 4 (RSU) dan 2 (RSB) di setiap kabupaten/kota, dalam rentang nilai terendah adalah 1 RSU di satu kabupaten, dan tidak terdapat RSB di salahsatu kabupaten, dan di sisi lain terdapat 22 (RS) dan 24 (RSB). Gambaran fasilitas kesehatan primer di Provinsi Sulawesi selatan, sebagai berikut: (1) di setiap kabupaten/kota terdapat 19 puskesmas dan 12 klinik, paling sedikit terdapat 6 puskesmas di salah satu kabupaten/kota dan terbanyak sebesar 46 puskesmas, dan 143 klinik, dalam rentang standar deviasi 8,59 (puskesmas), dan 208,89 (klinik).

Tabel 1 juga menyajikan rata-rata total belanja fungsi kesehatan di seluruh kabupaten/kota di Provinsi Sulawesi Selatan sebesar 221 M, dengan perincian terendah 119,3 M dan tertinggi sebesar 434,6 M. Rata-rata porsi terbesar anggaran fungsi kesehatan tersebut ada di Belanja Barang/Jasa (142 M), Belanja Pegawai (91 M), dan Belanja Modal (48 M).

Di sisi lain, tabel 2 menyajikan ringkasan rata-rata variabel untuk setiap zona. Tabel 2 di atas menyajikan ringkasan nilai rata-rata untuk setiap klaster zonasi, untuk semua karakteristik kabupaten/kota yang dipakai di dalam hierarki, yaitu: Indeks Kapasitas Fiskal (IKF), Tenaga Kesehatan, Realisasi Urusan Kesehatan, Realisasi Belanja Pegawai Urusan Kesehatan, Realisasi 
Belanja Barang/Jasa Urusan Kesehatan, Realisasi Belanja Modal, Realisasi Urusan Bantuan Sosial, Jumlah Penduduk, Kepadatan Penduduk, PAD, DAU, DAK serta Pendapatan Lain-Lain Yang Sah. Sedangkan karakteristik kabupaten/kota lainnya meliputi: Jumlah Dokter, Jumlah Perawat, Jumlah RSU, Jumlah Rumah Sakit Bersalin, Jumlah Puskesmas, Jumlah Klinik, Jumlah Posyandu, Jumlah pasien yang dirawat, Jumlah pasien yang sembuh, Jumlah Pasien yang Meninggal, serta Total Kasus Covid-19.

Tabel 2. Ringkasan Rata-rata Variabel untuk Setiap Klaster/Zona.

\begin{tabular}{lrrrr}
\hline \multicolumn{1}{c}{ Variabel } & \multicolumn{1}{c}{ Cluster 1 } & \multicolumn{1}{c}{ Cluster 2 } & \multicolumn{1}{c}{ Cluster 3 } & \multicolumn{1}{c}{ Cluster 4 } \\
\hline IKF & 0.32 & 0.84 & 0.17 & 0.50 \\
T_Kesehatan & $193,396,800$ & $236,089,300$ & $321,284,100$ & $434,680,300$ \\
U_Kesehatan & $173,147,500$ & $226,623,400$ & $302,095,000$ & $402,746,700$ \\
R_Pegawai & $84,030,720,000$ & $81,456,260,000$ & $125,558,800,000$ & $181,765,300,000$ \\
R_BarangJasa & $121,696,500,000$ & $144,980,000,000$ & $228,371,500,000$ & $300,713,300,000$ \\
R_Modal & $44,492,470,000$ & $38,758,800,000$ & $66,471,660,000$ & $111,923,000,000$ \\
R_Bansos & $1,320,318,000$ & $9,022,800,000$ & $1,188,775,000$ & 0 \\
Populasi & 295.76 & 191.53 & 465.65 & $1,526.70$ \\
Kepadatan & 232.47 & 600.25 & 288.00 & $8,686.00$ \\
PAD & $145,553,700,000$ & $186,483,600,000$ & $218,027,100,000$ & $1,749,403,000,000$ \\
DAU & $665,051,400,000$ & $559,560,700,000$ & $1,015,830,000,000$ & $1,408,063,000,000$ \\
DAK & $244,996,700,000$ & $180,543,400,000$ & $436,044,400,000$ & $350,545,400,000$ \\
PLLYS & $222,960,600,000$ & $185,072,300,000$ & $477,657,400,000$ & $537,013,700,000$ \\
Dokter & 94.24 & 109.25 & 125.50 & $1,836.00$ \\
Perawat & 480.00 & 518.50 & 758.50 & $4,619.00$ \\
RSU & 1.88 & 3.50 & 3.00 & 22.00 \\
RSB & 0.06 & 0.50 & 0.00 & 24.00 \\
Puskesmas & 17.65 & 12.25 & 32.00 & 46.00 \\
Klinik & 5.65 & 5.50 & 15.00 & 143.00 \\
Posyandu & 366.29 & 175.25 & 861.50 & 1.00 \\
Dirawat & 40.59 & 88.25 & 204.50 & $2,118.00$ \\
Sembuh & 29.88 & 127.00 & 162.00 & $2,112.00$ \\
Meninggal & 1.53 & 0.50 & 8.50 & 200.00 \\
Total_Kasus & 72.00 & 215.75 & 375.00 & $4,430.00$ \\
\hline SUt & & &
\end{tabular}

Sumber: dihitung sendiri, menggunakan RStudio package.

Di klaster 1, rata-rata total kasus sebesar 72 kasus. Sedangkan di klaster 2, rata-rata total kasus sebanyak 216 kasus. Rata-rata total kasus di klaster 3 sebanyak 375 kasus, dan rata-rata total kasus di klaster 4 sebanyak 4430 kasus. Sedangkan rata-rata kasus meninggal terbanyak ada di klaster 4 (200 kasus), rata-rata meninggal di klaster 1, 2, dan 3 berurut-turut 1,53; 0.5; dan 8.5. Untuk jumlah pasien sembuh, di klaster 4 sebanyak 2.112 orang, di klaster 1 (29.88), klaster 2 (127 orang), dan klaster 3 (162 orang).

Pada aspek kapasitas fiskal daerah, rata-rata indeks kapasitas fiskal tertinggi ada di klaster 2 $(0,84)$, berikutnya klaster $4(0,50)$, klaster $2(0,32)$, dan klaster $3(0,17)$. Menurut definisi dari Kementrian Keuangan (2019), kapasitas fiskal daerah adalah gambaran dari kemampuan keuangan masing-masing daerah yang dicerminkan melalui pendapatan daerah dikurangi dengan pendapatan yang penggunaannya sudah ditentukan, belanja bagi hasil, belanja bantuan keuangan dan belanja pegawai. Kementrian Keuangan (2019) telah mengelompokkan Indeks Kapasitas Fiskal Daerah menjadi 4 (empat) kelompok, yaitu IKFD < 0,509 (sangat rendah), IKFD di rentang nilai 0,509-0,720 (rendah), IKFD di rentang nilai 0,720-1,089 (sedang), IKFD di rentang nilai 1,089-1,959 (tinggi), dan IKFD lebih besar dari 1,959 (sangat tinggi). Dapat kita baca dari table 1 di atas, bahwa kabupaten/kota yang berada di Cluster 2 mempunyai kemampuan keuangan daerah di kategori sedang. Sedangkan kabupaten/kota di Cluster 1,3, dan 4 memiliki kategori kemampuan keuangan sangat rendah. Menjadi indikasi awal, bahwa kabupaten/kota yang berada di klaster 2 mempunyai ketahanan (resilient) dari segi kemampuan keuangan daerah di banding 
kabupaten/kota yang ada di zona lainnya. Dan menjadi indikasi awal, untuk mengatakan bahwa dari segi kemampuan keuangan daerah, kabupaten/kota di klaster 1,3, dan 4 mempunyai kerentanan (vurnerability).

Pada aspek rata-rata jumlah belanja fungsi kesehatan tersebut, tertinggi didominasi belanja barang dan jasa 300,7 M (klaster 4) dan 121,7 M (klaster 1). Berikutnya, rata-rata kabupaten/kota di klaster 1 melakukan pelaksanaan anggaran belanja pegawai sebesar $84 \mathrm{M}$, klaster $2(81,5 \mathrm{M})$, klaster $3(125,5 \mathrm{M})$, dan klaster 1 (181,7 M). Dari segi pengeluaran belanja pemerintah daerah urusan bantuan sosial, sampai makalah ini ditulis, realisasi untuk bantuan sosial di klaster 4 masih nol. Hal ini dapat diartikan, bahwa datanya masih belum terlaporkan ke Sistem Informasi Keuangan Daerah Kemenkeu (Ditjen Perimbangan Keuangan).

Tabel 3. Karakteristik Kewilayahan untuk Setiap Klaster/Zona.

Klaster 1

Klaster 2

Bulukumba, Bantaeng, Jeneponto, Takalar, Sinjai, Selayar, Luwu Timur, Parepare, dan Palopo

Maros, Pangkep, Barru, Soppeng, Wajo, Sidrap, Pinrang, Enrekang, Luwu, Tana Toraja, Luwu Utara, dan Toraja Utara

- Rata-rata kepadatan penduduk paling rendah.

- Kumulatif Covid-19 paling rendah yang menunjukkan paling rendah risiko penyebaran Covid-19.

- Rata-rata kepadatan penduduk lebih tinggi dibanding cluster 1 dan 3.

- Rata-rata dana bantuan sosial paling tinggi.

- Kumulatif kasus Covid-19 lebih rendah dibanding cluster 3 dan 4 dan lebih besar dari cluster 1 . Hal ini seiring dengan rata-rata jumlah dokter dan perawat yang hanya lebih besar dari cluster 1.

\begin{tabular}{|c|c|}
\hline Klaster 3 & Klaster 4 \\
\hline $\begin{array}{l}\text { Gowa dan Bone } \\
\text { - Kepadatan penduduk hanya lebih besar dari } \\
\text { cluster } 1 . \\
\text { - Kumulatif Covid-19 terbesar kedua setelah } \\
\text { cluster } 4 \text {. } \\
\text { - Sumber daya jumlah dokter dan perawat } \\
\text { terbesar kedua setelah cluster } 4 .\end{array}$ & $\begin{array}{l}\text { Makassar } \\
\text { - Kepadatan penduduk paling besar. } \\
\text { - } \quad \text { Kumulatif Covid-19 paling besar. } \\
\text { - Jumlah dokter dan perawat paling besar. }\end{array}$ \\
\hline
\end{tabular}

Sumber: Ringkasan interpretasi penulis, dari dendrogram.

Tabel 2 menyajikan ringkasan interpretasi penulis atas dendrogram klaster berjenjang untuk 4 (empat) wilayah zonasi, sebagai berikut. Klaster 1 berkarakteristik mempunyai rata-rata kepadatan penduduk paling rendah, dan kumulatif kasus Covid-19 relatif paling rendah sampai saat ini. Kemudian klaster 2 mempunyai karakteristik angka kepadatan penduduk lebih tinggi dibandingkan klaster 1 dan 3. Kabupaten/kota di klaster 2 juga mempunyai komitmen menggelontorkan belanja fungsi urusan bantuan sosial paling tinggi. Di sisi lain, kumulatif kasus Covid-19 nya masih relatif rendah dibandingkan klaster 3 dan 4, tetapi lebih tinggi dari klaster 1. Yang menarik, kabupaten/kota di klaster 3 ini mempunyai rata-rata jumlah dokter dan perawat yang relative lebih banyak dibandingkan rata-rata jumlah tenaga medis di kabupaten/kota yang ada di zona klaster 1 . Kabupaten Gowa dan Bone, yang terletak di klaster 3 mempunyai karakteristik, yaitu kepadatan penduduknya hanya lebih besar dari kabupaten/kota di klaster 1. Dan mempunyai sumber daya jumlah dokter dan perawat terbesar kedua setelah klaster 4 . Hal lain yang rentan, selain keduanya terletak berdekatan dengan pusat pandemi Covid-19 di Provinsi Sulawesi Selatan, kumulatif Covid19 saat ini relatif besar, urutan kedua setelah cluster 4. Yang paling rentan, tentu saja saat ini adalah Kota Makassar, dengan karakteristik kepadatan penduduk terbesar dibanding kabupaten/kota di klaster 1, 2, dan 3, angka kumulatif Covid-19 nya relatif paling tinggi sampai saat ini di Provinsi Sulawesi Selatan. Satu-satunya yang menunjukkan ketahanan (resilient) adalah jumlah dokter dan perawat yang relatif terbanyak dibanding kabupaten/kota lain yang ada di klaster 1,2, dan 3. Tetapi, bila tidak disikapi dengan baik, misalkan dengan pengambilan kebijakan yang kurang komprehensif, didukung sikap masyarakat yang abai terhadap protocol kesehatan, faktor ketahanan dari sudut pandang faktor penawaran pejuang medis ini bisa jadi berbalik menjadi kerentanan. 


\section{KESIMPULAN}

Hasil akhir dari karya tulis ini adalah tersampaikannya peta zonasi dan plot dendrogram hierarchical clustering tingkat provinsi, sampai dengan tingkat kabupaten kota di Provinsi Sulawesi Selatan. Adanya peta tematik yang komprehensif memuat clustering kabupaten/kota, dan karakteristik kewilayahan akan dapat menjadi early warning (peringatan dini) stakeholder decision maker terkait penanganan pandemi Covid-19 khususnya di Provinsi Sulawesi Selatan. Dengan zonasi clustering berjenjang, dapat diketahui kabupaten/kota yang memiliki kemiripan karakteristik, yaitu kasus kumulatif Covid-19 sejauh apa saat ini, dan angka kepadatan penduduknya seperti apa, juga jauh atau tidaknya dari pusat penularan Covid-19 di Provinsi Sulawesi Selatan (epicentrum).

Saran sementara dari kajian ini yang dapat kami usulkan kepada pemerintah di provinsi Sulawesi Selatan adalah peningkatan kualitas koordinasi tanggap darurat Covid-19, contohnya di dalam pembatasan mobilitas penduduk. Bila mau melakukan kebijakan perpanjangan Pembatasan Sosial Berskala Besar (PSBB), misalnya, pemerintah daerah zona 4 dan 3 harus kompak, terutama membatasi mobilitas penduduk dari dan ke klaster 2 dan 1 dengan resiko rendah. Usulan lain berikutnya, pertimbangan realokasi bantuan langsung dari daerah di klaster 1 dan 2 untuk daerah di klaster 3 dan 4, tentu saja dengan tetap memperhitungkan kewenangan dan aturan payung hukum pelaksanaan anggaran Pemda yang berlaku.

Meskipun berhasil menampilkan secara deskriptif zonasi karakteristik kabupaten/kota di Provinsi Sulawesi Selatan menghadapi pandemi Covid-19, temuan kami memiliki kelemahan, yaitu: Pertama, kajian kami masih bersifat eksploratif, dan belum melakukan seleksi variabel yang ketat dan mendalam. Kajian yang mendalam sangat diperlukan misalnya untuk dasar penyusunan indeks ketahanan maupun indeks kerentanan daerah, khususnya di Provinsi Sulawesi Selatan, untuk kesinambungan kebijakan tanggap darurat pandemi Covid-19. Penelitian selanjutnya harus mempertimbangkan seleksi variabel yang lebih ketat dan relevan, sehingga menghasilkan makalah kebijakan yang lebih tajam rekomendasinya untuk pemerintahan daerah. Kedua, penelitian kami belum menyertakan kemampuan kapasitas keuangan pemerintah Provinsi Sulawesi Selatan, dan karakteristik provinsi. Kajian mendatang perlu untuk memadukan data provinsi dan kabupaten/kota, supaya lebih bisa memotret karakteristik permasalahan pembangunan di kesatuan wilayah provinsi tersebut, baik di level provinsi maupun di level pemerintahan kabupaten/kota.

\section{DAFTAR PUSTAKA}

Worldometer.2020.https://Www.worldometers.info/coronavirus/?utm_campaign=homeAdvegas1?

$\% 22$ \#countries (web diakses 23/7/2020 pukul 07.30 WIB).

Kassambra, Alboukadel. 2017. Practical Guide to Cluster Analysis in R Unsupervised Machine Learning. STHDA.

Kumar, S. (2020). Monitoring Novel Corona Virus (COVID-19) Infections in India by Cluster Analysis. Annals of Data Science, 1.

Larasati, Annisa. 2017. Metode K - Medoids pada Data dengan Pencilan. Skripsi. FMIPA UGM. Yogyakarta.

Pemerintah Indonesia. 2019. Peraturan Menteri Keuangan Republik Indonesia Nomor 126/PMK.07/2019 Tentang Peta Kapasitas Fiskal Daerah. Jakarta.

Poompaavai, A., \& Manimannan, G. (2019). Clustering Study of Indian States and Union Territories Affected by Coronavirus (COVID-19) using k-means Algorithm. International Journal of Data Mining And Emerging Technologies, 9(2), 43-51. 
Seminar Nasional Official Statistics 2020: Pemodelan Statistika tentang Covid-19

Srivastava, A., \& Chowell, G. (2020). Understanding Spatial Heterogeneity of COVID-19 Pandemic Using Shape Analysis of Growth Rate Curves. medRxiv.

Sulsel Tanggap COVID-19. https://covid19.sulselprov.go.id/ (web diakses 23/7/2020 pukul 08.27 WIB). 